\title{
AESTHETICS AND PERCEPTION OF MOBILE REALITY: ARCHITECTURAL PROSPECTIVE
}

\section{A B S T R A C T}

This article discusses a possibility that the notion of mobile reality, as theorised by a few important philosophers at the beginning of the twentieth century, and contemporary architectural ideas, could be complementary according to dynamic characteristics of aesthetic perception and experience. This, at first glance odd statement, could be justified by the relative similarity that philosophical and architectural ideas at the beginning of the twentieth and the twenty-first century expose through fundamental characteristics of their appearance. As a matter of fact, dynamic aesthetic sensations are the essential values of avant-garde understanding of architectural and urban design, and the notion of mobile reality is one of its fundaments. These ideas could be applied on diverse design approaches and dynamic aesthetic sensations of contemporary architecture. 
As the second decade of this century gets closer to its end, the issues in architectural theory and practice seem to multiply in a more diverse way. The appearance of new approaches to the essential aspects of designing and building our living environment continuously restarts the effort in focusing on permanent aspects of architecture. The only permanent sense appears to be the continuous dynamism of change. Consequently, a critique appears regarding aesthetics as increasingly powerless discipline, unable to manage the issue of constant reevaluation of contemporary challenges in architectural and urban design. It seems that aesthetic theories regarding the art of building through an exclusive evaluation of solid form are possible saturated with displaced theoretical discussions able to manage only the issues on the margins of contemporary architecture embracing diverse aspects of dynamic perception. Designing is not only about producing a tension between framed values and temporal qualities, but also about establishing essentially different realities of aesthetic perception and experience.

As this condition undoubtedly relies on the process of development of new concepts in architecture and aesthetics at the beginning of the twentieth century, we will reflect on a few philosophical concepts of that time, trying not to discuss them in detail, but possibly to find inspiration useful for our further debate.

The expression used in the title of this paper, 'mobile reality', is borrowed mainly from Bergson's ideas regarding the essential relationship between human inner self and external sensations. In a way, it determinates the crucial understanding of what dynamism in its basic appearance can be.

In his Introduction to Metaphysics, Bergson defines reality as mobility if external to our inside. ${ }^{1}$ This notion is from a particular interest for our discussion, while mobile reality means a constant change of directions in idealising our own understanding of what that reality really means. By this point, mobile reality is linked to our state of mind, to someone's view of reality. If an absolute movement can be conducted by intuition, as Bergson emphasises, using the effort of imagination, we can understand that constant change of social and cultural conditions, depend on a number of coordinated personal understandings what reality could be, and how these fragments can be united into a transformable power of development. In this context we can think of reality as a dynamic sense of life, transformable in a fluid and mobile process.

In this context, the sense of transformable reality refers to complexity in the process of constant development of social and cultural issues, creativity and aesthetic viewpoints. It indicates the need for everyday efforts within a society 
for keeping this process ongoing. By this, everyday life improving political, economical, cultural, and social aspects, forms a powerful potential for breaking already achieved and established standards in these fields. Moreover, even condition of aesthetic perception and evaluation has been thought as depending on the everyday life dynamism, correlating to all other social aspects involved in the process. In his first lecture on aesthetic, Bosanquet emphasises that aesthetic "is to consider where in life the aesthetic attitude is to be found, and what is its peculiar form of value, as distinguished from other attitudes and objects in our experience. It is not to prescribe rules for the production of beauty, or for the criticism of artist's work." ${ }^{2}$ In that sense, as aesthetic recognizes and analyses "forms of reality and their values", aesthetic sensibility can be thought as a product of life's reality developed in a particular moment and by that changeable.

The analysed process is essentially related to our integrated memory as the power which "keeps the mind of one man single." "It is an important form of social communication, which also enables development of our capacity for aesthetic perception. Without memory we wouldn't be able to manage the nature of fluid or mobile reality (call it as you wish), or to initiate and maintain continuous transformations as essential power of social and cultural development of the human society. Moreover, memory is fundamental for our ability to experience fragments of reality we aesthetically perceive and communicate as endless source of creativity. Even if the perceived object is immobile, the process of aesthetic perception and evaluation increases the capacity of memory, changing the quality of the next new vision, in comparison to the previous vision of the same object. ${ }^{4}$ In this sense, aesthetic perception can be thought as a process of creation of perceiver's own sensible and imaginative world. The process of experiencing fragmented reality of space through time enriches one's memory, activating apparatus for the continuous process of personal, individual aesthetic growth.

However, at this point of our debate one can ask a simple question: how the issues we discussed are reflecting on the aesthetic perception and experience in architecture? To give a potential answer it seems to be more than helpful to analyse architectural examples, through which a further understanding and clarification of debated issues can be reached. For this purpose, the analysis of perception and experience of two buildings will be sufficient. The first of them is the Sidney Opera House, completed in 1970, and the second one the Olympic Stadium in Beijing, from 2008.

It seems that there are mainly two slightly different processes regarding aesthetic perception of Utzon's building. The first one can be named as the process of uncovering the character of the form and structure of the building, and the other 
as searching for it. It can be said that these two processes are closely linked to the state of perceiver's previously reached knowledge on the building's visual properties, or the lack of it.

Let us analyse the possible process of aesthetic perception of a person who has never encountered any information regarding the form and structure of the Sidney Opera House. Approaching it from the city side, at first glance the perceiver can experience the building from the left flank (Figure 1). At that position, one can reach a vague sense of the building's size and form. It partly reveals the character of the structure, where the base mass of the exterior walls and the front stairway are dominating over the white shell-like forms on the top of it. Further movement over the large front stairway offers particularly surprising visual sensation. The strong lower mass of walls disappears, and the shell-like forms start to dominate the perceptual field. As one reaches the entrance platform on the top of the staircase, the sense of a large, massive building is replaced by a number of shell-like forms, perceived as glassed envelope structures (Figure 2). At that position, the perceiver is experiencing sensations caused by the arrangement of separated forms, which is confronted with the impression got at first glance from the ground level. For a person ignorant in what the complete building's form and structure look like, it is a moment of perceptual confusion. When the particles of a whole are building up separate and diverse, but real sensations, in perceiver consequently arises a need for uncovering the character of the whole structure. This is by its nature a dynamic process which in our example can be completed but through a particular time period sufficient for recomposing, until then separated sensations and individual experiences acquired by walking through and around the building structure. However, there is still a question: does the general look at the building from the seaside contribute to the perception of the 'real' form of the opera house, or can it be thought of as just one more visual particle increasing the sense of the diverse character of the whole structure?

Being the most complete general view on the Sydney Opera House, the sea side look was the most exploited image in the history of this Utzon's architectural work (Figure 3). It reveals the powerful compositional role of the shell-like forms, as almost metaphorical image overtaking the notion of that what is the 'reality' of the building's perceptual quality. Many generations of architects and other people educated in art identified the formal architectural character of the Opera House with that exact representation. However, that image has little to do with the sensations that we just analysed when approaching the building from the city centre. Actually, one can see the other side just occasionally, sailing from the Darling harbour towards the open sea, and back. At first glance, the approaching educated person sense a kind of disappointment with the look of 

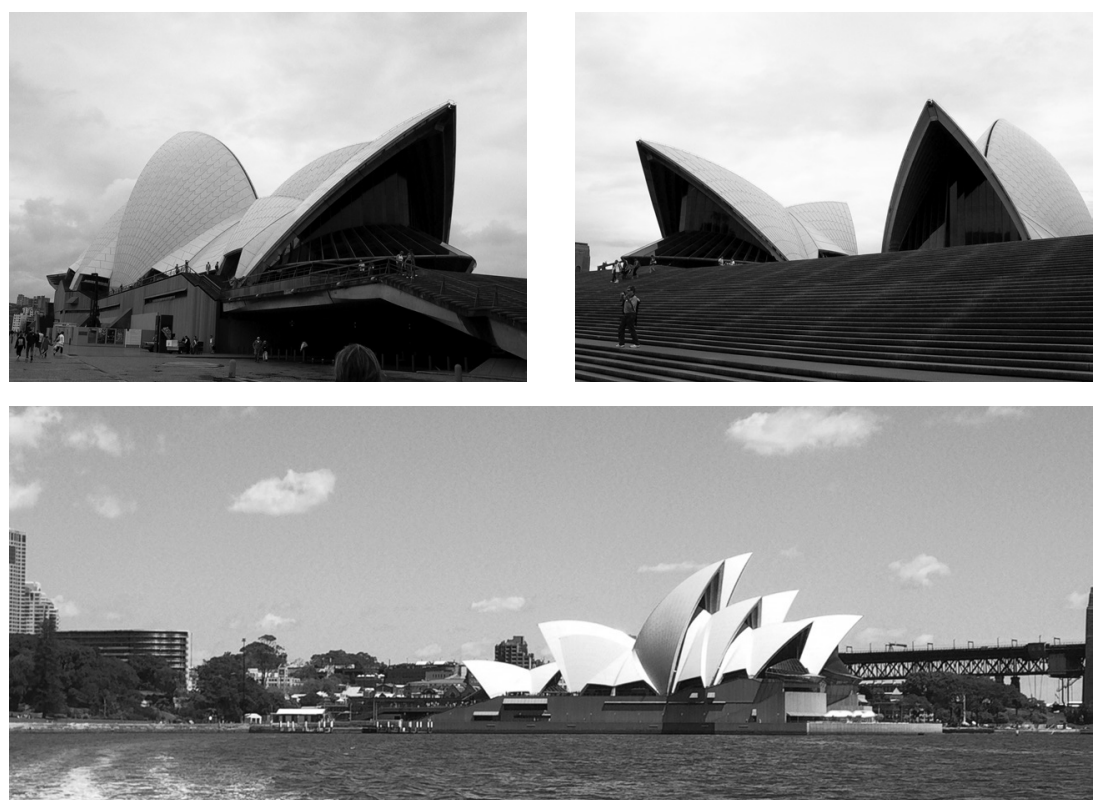

Figure 1-3. Utzon, Sidney Opera House, 1970.

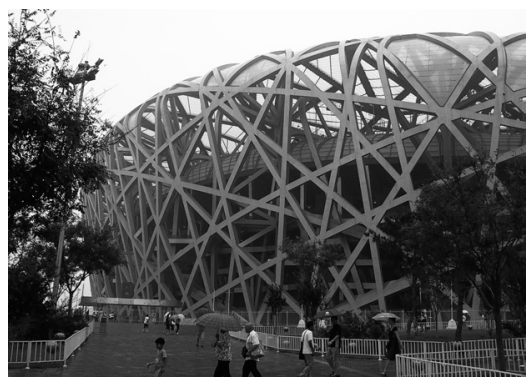

Figure 4. Herzog and De Meuron,

Olympic Stadium, Beijing, 2008. General view.

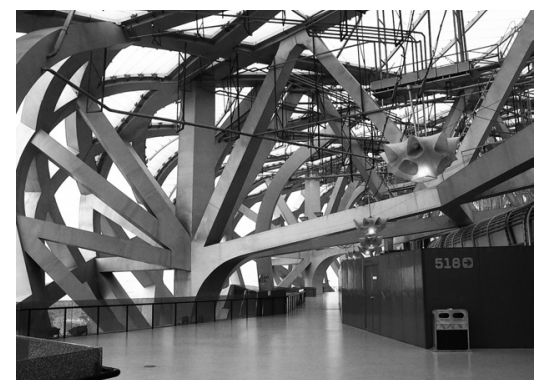

Figure 5. Herzog and De Meuron,

Olympic Stadium, Beijing, 2008. Interior particle.

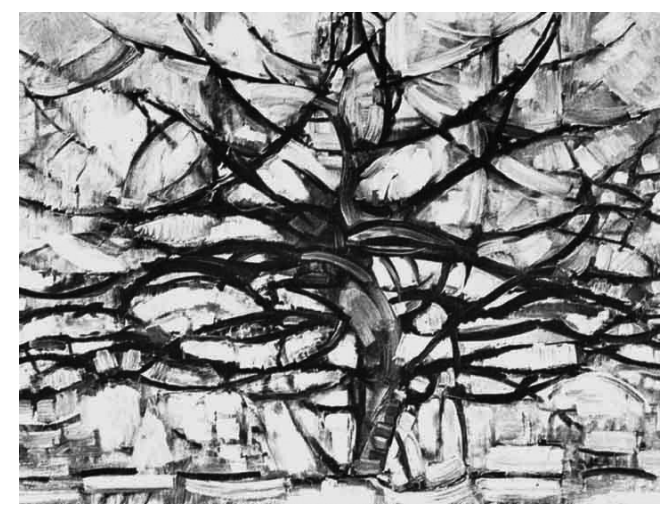

Figure 6. Mondrian, The Gray Tree, 1912, Hague, Gemmentemuseum. 
the building. There is even a possible rhetorical question: am I on the correct spot? Am I looking at the wrong building? At that moment the visible particles of the shell-like forms are indicating the correctness of the site, identifying the building intuitively. From that point, the perceiver is entering into the process of searching for the 'real' look of the building, intuitively enriching its own experience with particular variables of other 'realities' of the structure. At the end of this process, at least at that first searching quest, the perceiver is fulfilling its aesthetic perceptual capacity with diverse, but important experiences of new values. To an attentive 'searcher' of the formal and structural reality of the building, the process demonstrates the importance of the dynamic perception, forming sense and experience of mobile reality, and the potential capacity of memory in creative reconstruction of the image of the whole structure.

The second architectural example, the Olympic Stadium in Beijing designed by Herzog and De Meuron, reveals a different kind of dynamic perceptual process related to the sense of mobile reality. It engages subjective reflections on aesthetic values and metaphorical associations, guided by the perceiver's memory, intellectual and imaginative capacities. Moreover, the perceptual dynamism is based on the sense of shifting from three-dimensional into twodimensional reality, changing the perceptual quality from generally solid form towards a pictorial imaginative reflection. The general visual characteristic of the building's façade already contributes to this perceptual process, combining a sense of solid form with the visible structural elements presented as twodimensional graphic like surface (Figure 4). However, after entering the building, the patterns like structure transforms into a number of three-dimensional particles penetrating into the interior space. Their tree like structure is, however, converted into an almost abstract perceptual value, by the means of their metal quadrilateral trunks and branches (Figure 5). Undoubtedly, these structures contain an associative potential, provoking our imagination and shifting it into a subjective creative domain, because, as Bergson emphasises, aesthetic intuition which is here at work "only attains the individual." through an abstracted grove, easily awake parallels with pictorial abstractions as, for instance, those of Mondrian (Figure 6). Such a parallel between the 'reality' of interior structure and 'reality' of its pictorial counterpart, confirms the notion that even a result of deeply subjective imagination should be thought of as a part of a number of successive realities. The sensitive aesthetic properties of all these realities are mobile and they are passing from one stage to another increasing their creative potential as the capacity of memory. The fact that this succession can be shared between a number of perceivers as a visible and comprehendible value, proves the consistent reality of all parts. 
The analysed examples are suggesting that aesthetic perception and evaluation of existing forms of reality, as process of developing inner creative sensitivity always produce a new reality. It seems that this process can be clarified according to Bosanquet's philosophical position by which the "embodiment of aesthetic feeling can only be an object as we perceive or imagine it." By this, the semblance of an object composed by a number of perceptual fragments appearing in a successive flow of images is valued above the reality of fixed formations. It is strongly linked to memory and imagination as creative aesthetic potentials, but also to the perceiver's "own activities in approaching" the object, in order to "compose the feeling of the object or the object as an embodied feeling." ${ }^{77}$ According to these potentials, aesthetic perception produce a number of successive realities, composing them into a kind of emotional mobile reality. It proves Bergson's idea that all reality is tendency as an incipient change of direction in perceiving and imagining. ${ }^{8}$ In this context, the factual properties of an object exist in principle, but its aesthetic reality is linked to the mobile successive transformation of perceptual values. 
Bergson, Henri. An Introduction to Metaphysics. London: Macmillan and Co., 1913.

Bosanquet, Bernard. Three Lectures on Aesthetic. London: Macmillan and Co., 1923.

Delisle, Burns. The Contact Between Minds. London: Macmillan and Co., 1923.

Bergson, Henri. Creative Evolution. London: Macmillan and Co., 1928. 


\section{OSNOVNA PITANJA I ZNAKOVI - ESTETIKA ARHITEKTURE Miško Šuvaković}

U ovom radu autor postavlja osnovna pitanja o estetici arhitekture. Arhitektura, kao strateški dispozitiv zgrade/građevine, i urbanizam, kao strateški dispozitiv grada, transformišu prostorno (geografsko) i vremensko (istorijsko) stanje u dispozitiv oblika života, čime se razvijamo kao pojedinci i zajednice ljudi u našim pojavnim oblicima prostora i vremena u određenom trenutku. Zato je neophodna politizacija građevine - arhitektonska i umetnička - arhitektonske prakse. To znači pokazati gde se organizacija životnog prostora suprotstavlja organizaciji načina života pojedinca i zajednice. Politika arhitekture je antropologizovana, a to znači da arhitekte/gradski planeri rade tako da arhitekturu orjentišu prema objektu ili odnosu objekata koji utiču na ljudski život svojim svakodnevnim fleksibilnim i složenim intimnim, privatnim i javnim izgledom.

KLJUČNE REČI: ARHITEKTURA, ESTETIKA ARHITEKTURE, DISPOZITIV, NAČINI ŽIVOTA, PRAKSA

\section{ESTETIKA I SHVATANJE MOBILNE REALNOSTI: ARHITEKTONSKA PERSPEKTIVA \\ Vladimir Mako}

U ovom radu se raspravlja o mogućnosti da ideja mobilne realnosti iz teoretske perspektive nekoliko značajnih filozofa sa početka dvadesetog veka I savremenih arhitektonskih ideja budu komplementarne po dinamičkim karakteristikama estetske percepcije I iskustva. Ova, na prvi pogled čudna izjava, mogla bi se opravdati relativnom sličnošću filozofskih I arhitektonskih ideja početkom dvadesetog I dvadeset prvog veka, izloženih kroz njihove osnovne karakteristike. U stvari, dinamički estetski doživljaji su osnovne vrednosti avangardnog razumevanja arhitektonskog I urbanog dizajna, a ideja mobilne realnosti je jedna od njihovih osnovnih ideja. Ove ideje bi se mogle primeniti u različitim pristupima dizajna I dinamičkih estetskih doživljaja u savremenoj arhitekturi.

KLJUČNE REČI: ARHITEKTURA, MOBILNA REALNOST, ESTETIKA, PERCEPCIJA

\section{ESTETIKA PREĆUTANOG: \\ ARHITEKTONSKA FORMA I VIDLJIVA GRANICA JEZIKA \\ Vladimir Stevanović, Andrea Raičević}

Stonborough House je kuća u gradskom tkivu Beča na čijem je dizajnu i realizaciji austrijski filozof Ludvig Vitgenštajn učestvovao zajedno sa arhitektom Polom Engelmanom učenikom Adolfa Losa, na predlog svoje sestre Margaret Stonbro-Vitgenštajn. U pokušaju da se Vitgenštajnova filozofija dovede u vezu sa njegovim radom kao arhitekte, kuća Stonborough često je imenovana 'vidljivom formom njegovih učenja'. Ovaj rad ima za cilj da pokaže da je prevođenje na zamenski jezik arhitekture dobilo smisao kroz bavljenje filozofskim pitanjima i da je kredo Vitgenštajnove filozofske etike - uzdržavanje od izlišnog, pronašao artikulaciju svoje estetske vrednosti posredstvom arhitektonske retorike. 